\title{
Implementation of Sell and Purchase in Steam Online Game Platform Based on Steam Subcsriber Agreement
}

\author{
Dewi Septiana \\ Law Faculty \\ Lampung University \\ Lampung, Indonesia \\ dewiseptiana80@yahoo.co.id
}

\author{
Wati Rahmi Ria \\ Law Faculty \\ Lampung University \\ Lampung, Indonesia \\ watirahmi87@gmail.com
}

\author{
Kingkin Wahyuningdiah \\ Law Faculty \\ Lampung University \\ Lampung, Indonesia \\ kingkinshmh@gmail.com
}

\begin{abstract}
Many games entertainment has switch to digital or commonly called as online game. Game service providers are also developing, one of which is VALVE, which makes a game platform called Steam. Steam is a platform that sells games and non-game software. However, there are problem that arises. Which are, how is the implementation of the sale and purchase agreement based on the Steam Subscriber Agreement between Steam users and The Steam itself? And what are the obstacles that occur in the implementation of the sale and purchase agreement on this steam platform? The longterm goal of this research is to form the basis of government policies in accordance with the principles of buying and selling agreements. The policy basis in the form of regulations is needed regarding the obstacles faced by online game platform users. Users/users of online game platforms expect legal protection in the implementation of this sale and purchase agreement, because they are always in a weak position that does not have a bargaining position. This research uses a statutory approach. a statutory approach is used to map the basis of government authority in regulating sale and purchase agreements on the online game platform steam.
\end{abstract}

Keywords-Sell and Purchase Agreement, Game Online Platform, User

\section{INTRODUCTION}

One that is developing through the internet is the game. Games in this modern era have undergone changes, the change is that there have been games that have been shaped into digital or commonly referred to as online games. The development of games, both abroad and in Indonesia, game service providers also continued to grow, one of which is an American computer game developer and publisher company, VALVE, which makes a game platform called Steam. Where in this steam is a place that not only sells games but also non- game software. Steam continues to innovate to build its platform by inviting other parties, which in this case are other game developers, to participate in placing or selling their games on their platform. Steam itself is a game platform with the highest number of users recorded in February 2020, users of this service have reached 18 million online users, which is global data [1] In its own development, online games are more in demand because players who play similar games can connect via an internet connection without distance restrictions, unlike offline games which are mostly played alone by the players.

Trading on the internet in this era is not something foreign since the discovery of technology that supports humans such as cellphones and PCs shopping in cyberspace can be done by simply clicking on the desired image, it is through these ways that business developers make new innovations, they created a variety of websites that can be used to shop online. With the increasing sophistication of the internet and the web, these technologies increase the ability of both individuals and companies or organizations to develop business and technology [2] The electronic system according to the law is a set of tools and procedures for disseminating electronic information [3] The arrangements contained in the object law are also classified based on their form and principle, where there are tangible objects or intangible objects, for example, intangible objects are objects contained in video games or in terms known as virtual property.

The agreement is part of buying and selling, including buying and selling carried out on the internet the validity of a virtual object in the context of trading that occurs on a game platform whether or not it is in accordance with applicable law in Indonesia, because these objects are not tangible objects that only exist. connected through the digital world where at any time these objects can be lost or change ownership. Because without realizing there is a form of contract that is often ignored by users. 
Based on the background described, the problems to be solved in this research are:

- How is the implementation of the sale and purchase agreement based on the Steam Subscriber Agreement between Steam users and The Steam itself?

- What are the obstacles that occur in the implementation of the sale and purchase agreement on this steam platform?

\section{STUDY METHOD}

The research method uses a case study method with various data collection techniques such as observation, historical tracing, key informant interviews. This study uses a qualitative approach. Corbin and Strauss (2014) define qualitative research as a research method whose findings are not obtained through statistical procedures or other forms of calculation [4]. Data analysis used qualitative analysis. Operationally, qualitative research data analysis is the process of compiling data (categorizing it into themes or categories) so that it can be interpreted or interpreted. Data collection and analysis activities in this study are not separate from each other.

This research is conducted within 6 months and will result in the identification of dynamic capability variables that have been and have the potential to be carried out by the parties in entering into an agreement. Dissemination of research results is very important, so that the parties and the general public will know how the position of the agricultural land agreement claimed by these parties is.

\section{DISCUSSION}

A. The Implementation of The Sale and Purchase Agreement based on The Steam Subscriber Agreement between Steam Users and The Steam itself.

The implementation of the sale and purchase agreement based on the Steam Subscriber Agreement is based on 3 stages in the agreement based on the new theory, namely:

- Pre-Contractual Stage

- Contractual Stage

- Post Contractual Stage

1) Pre-Contractual Stage

At this stage, both parties negotiate or offer and accept. Electronic transactions according to Article 1 number 2 of the ITE Law are "legal acts carried out using computers, computer networks, and/or other electronic media [5]. This Steam Subscriber Agreement is included in an electronic contract, and the legal requirements of an agreement based on article 1320 of the Criminal Code have been fulfilled, namely: a) There is an agreement for those who bind themselves: The parties, namely the User and Steam, have agreed on this sale and purchase agreement based on the trust set forth in an electronic agreement.

b) The ability of the parties to enter into an engagement: The parties have fulfilled the elements of legal competence so that in the pre-contractual process this sale and purchase agreement was made consciously without any pressure from certain parties.

c) A Certain Thing: An agreement must have a clear object. The object is not only in the form of goods in physical form, but can also be in the form of services that can be determined by type. According to the contents of point 1 letter b: As a Subscriber you may obtain access to certain services, software and content available to Subscribers. The Steam client software and any other software, content, and updates you download or access via Steam, including but not limited to Valve or third-party video games and ingame content, software associated with Hardware and any virtual items you trade, sell or purchase in a Steam Subscription Marketplace are referred to in this Agreement as "Content and Services;" the rights to access and/or use any Content and Services accessible through Steam are referred to in this Agreement as "Subscriptions". Which is basically our goal of making a deal is to get access to games that we will later buy and play.

d) Lawful Cause: It is related to the content of the agreement. The Steam Subscriber Agreement has twelve (12) main points in its contents, all of which have explained in detail the contents of the agreement without any rules that violate the laws of a country.

\section{2) Contractual Stage}

The contractual stage is the stage of conforming the statement of will between the parties. Usually, the contractual stage is marked by the signing of a written contract signed by both parties. The sale and purchase agreement carried out electronically so that the contractual stage is marked by an agreement between the two parties by pressing the click (agree) on the transaction section.

\section{3) Post Contractual Stage}

The post-contractual stage is the stage of implementing the agreement that has been agreed upon by both parties. The agreement will end at the post contractual stage. The end of the agreement can be in two ways, the agreement is completed according to the time specified in the agreement or the agreement is not completed because one of the parties is in default.

\section{B. The Obstacles that Occur in The Implementation of The Sale and Purchase Agreement on this Steam Platform}

Steam subscriber agreement is a standard contract where this electronic contract is made unilaterally by a stronger party, namely Steam (service provider). Users 
as consumers in carrying out activities using products or services provided or created by Steam do not have the same power in the contract. In practice this is one of the obstacles that occur in the implementation of this agreement. Users often experience losses when using products from Steam, but because the buying and selling transactions carried out by Steam can be said to be legal transactions because Steam does not do anything that can injure or harm the user as a consumer and the value of the loss is not large so this is only is a minor obstacle. Users are still using this product from Steam. The next obstacle is that users are people who are not yet proficient, many children become users. Article 1320 of the Civil Code has written that a person is considered capable of engaging in an engagement when they are said to be adults, while Steam as a game platform service provider writes in the Steam Subscriber Agreement: This Agreement takes effect as soon as you indicate your acceptance of these terms. You may not become a subscriber if you are under the age of 13. Steam is not intended for children under 13 and Valve will not knowingly collect personal information from children under the age of 13. Ecommerce carried out by minor legal subjects is that the e-commerce agreement is considered invalid and can be canceled by one of the parties if it is proven that the ecommerce agreement was made by those who are not yet mature, in this case the party who can apply for cancellation is the immature party. If no cancellation is requested, the e- commerce agreement will still be binding on the parties who made it [6]. The reason why Steam makes a contract with a minimum age requirement of 13 years is because some games have ratings for children from 13 years old and above. This is also one of the weaknesses of the written agreement that exists in e-commerce today, because anyone can access it even if they are under the specified age.

\section{CONCLUSION}

Based on study result and discussion that already done by the researcher, the conclusion are:

- The Implementation of Sale and Purchase Agreement that based on Steam Subscriber Agreement has been done by the agreement valid conditions on 1320 KUHPdt. As for the stages in this agreement is done based on the stages in the new theory according to van dune which are pre-contractual, contractual, and postcontractual.

- The obstacle in this agreement is when the user of the game online didn't have the bargaining power to this sale and purchase of online game in steam agreement. It's because this agreement is in a standard form with a 'take it or leave it' concept. The next obstacle is many user parties are still underage, and that is because of the form of the agreement which is an electronic contract where the buyer and seller don't meet directly.

\section{REFERENCES}

[1] eurogamer.net/articles/2020-02-02-steam-just-hit-a-recordbreaking-18-8m-concurrent-users diakses pada 14 November 2020 jam 23.00 WIB.

[2] A. Nugroho. E-Commerce: Memahami Perdagangan Modern Di Dunia Maya. Bandung: Informatika. 2006.

[3] S. Sisiwanto. Hukum Informasi dan Transaksi Elektronik, Jakarta: PT. Raja Grafindo. 2009.

[4] J. Corbin, \& A. Strauss. Basics of qualitative research: Techniques and procedures for developing grounded theory. Sage publications. 2014

[5] Undang-Undang Nomor 19 tahun 2016 tentang Perubahan Atas Undang-Undang Nomor 11 tahun 2008 tentang Informasi dan Transaksi Elektronik.

[6] S. V. Bumi, \& A. A. S. Indrawati. SYARAT SUBJEKTIF SAHNYA PERJANJIAN MENURUT KITAB UNDANGUNDANG HUKUM PERDATA (KUH PERDATA) DIKAITKAN DENGAN PERJANJIAN ECOMMERCE. Kertha Semaya: Journal Ilmu Hukum. 2013. 